\title{
Lymphocyte mRNA as a resource for detection of mutations and polymorphisms in the CF gene
}

\author{
Gillian Chalkley, Ann Harris
}

The most common mutation in the cystic fibrosis gene, deletion of a phenylanaline residue at amino acid 508, occurs in about $70 \%$ of CF patients in North America and northern Europe. ${ }^{12}$ A collection of alternative mutations in the CF gene has already been defined by members of the CF Genetic Analysis Consortium. Most of these mutations have been detected by amplification of individual CF gene exons from genomic DNA followed by DNA sequence analysis. Clearly this approach is laborious since each of the 27 exons has to be analysed independently. An alternative means of searching for mutations is through the examination of mRNA. This would enable much larger segments of the gene to be examined at each analysis. However, this approach is not readily applied to CF since the CF gene is apparently only expressed at significant levels in tissues that are primarily involved in the pathology of the disease, such as the epithelium lining the lungs and respiratory system, pancreatic ducts, gut, and sweat gland ducts. ${ }^{13}$ Apart from nasal epithelium, such tissues are not readily available for mRNA analysis. To circumvent this problem we have developed a method to amplify the CF mRNA from peripheral blood lymphocytes. This method relies on cDNA synthesis, followed by two rounds of polymerase chain reaction using nested primers. ${ }^{4}$ 'Ectopic' transcription of other genes, including the dystrophin and factor VIII genes, has recently been detected in lymphocytes. ${ }^{5-7}$

Division of Medical and Molecular Genetics, United Medical and Dental Schools of Guy's and St Thomas's Hospitals, 8th Floor, Guy's Hospital Tower, London SE1 9RT.

G Chalkley, A Harris

Correspondence to Dr Harris, Paediatric Molecular Genetics, Institute of Molecular Medicine, The John Radcliffe Hospital, Headington, Oxford OX3 9DU.

Received for publication 26 March 1991.

Revised version accepted for publication 3 May 1991.
Lymphocytes were isolated from whole blood by Histopaque (Sigma) centrifugation. Cells were washed by phosphate buffered saline and then RNA was extracted by single step guanidinium thiocyanate phenol extraction. ${ }^{8}$ Alternatively, RNA was isolated from lymphocytes or lymphoblastoid cell lines by guanidinium thiocyanate lysis followed by caesium chloride centrifugation.9 The CF cDNA sequence was divided into eight segments ( $A$ to $H$ ) as is shown in fig 1 . Segments $A$ to $F$ broadly correspond to predicted functional domains of the protein, and segments $\mathrm{G}$ and $\mathrm{H}$ to the $3^{\prime}$ non-coding region of the mRNA. In order to amplify the CF cDNA from lymphocyte RNA, in which the CF gene message is represented at an extremely low level, it was necessary to have two 30 to 35 cycle rounds of polymerase chain reaction (PCR) for each segment, using nested sets of primers. The primer sequences are shown in the table. The first round of PCR was carried out using primer set 1 following cDNA synthesis primed by the $3^{\prime} 20$-mer (IL) of each PCR reaction. The second round of PCR amplification was done using primers located inside those used in the first round reaction (primer set 2). Fifty nanograms of the $3^{\prime}$ primer for each CF gene segment was annealed to 0.5 to $1 \mu \mathrm{g}$ of total RNA at $65^{\circ} \mathrm{C}$. $\mathrm{cDNA}$ was synthesised from this primer with reverse transcriptase (Gibco BRL) in $50 \mathrm{mmol} / 1$ Tris- $\mathrm{HCl}, \mathrm{pH} 8 \cdot 5,75 \mathrm{mmol} / 1 \mathrm{KCl}, 5 \mathrm{mmol} / 1 \mathrm{DTT}$, $3 \mathrm{mmol} / 1 \mathrm{MgCl}, 1.25 \mathrm{mmol} / \mathrm{lNTPs}$, and 50 units of placental ribonuclease inhibitor (Boehringer, Mannheim) in a total volume of $20 \mu \mathrm{l}$ at $42^{\circ} \mathrm{C}$ for 60 minutes. To this was added $30 \mu 1$ of a premix of PCR buffer containing $67 \mathrm{mmol} / 1$ Tris- $\mathrm{HCl}$, pH $8.8,167 \mathrm{mmol} / 1\left(\mathrm{NH}_{4}\right)_{2} \mathrm{SO}_{4}, 6.7 \mathrm{mmol} / 1 \mathrm{MgCl}_{2}$, $0.17 \mathrm{mg} \mathrm{ml}^{-1}$ BSA, $0.07 \% \beta$-mercaptoethanol, $500 \mathrm{ng}$ of the $5^{\prime}$ primer, $450 \mathrm{ng}$ of the $3^{\prime}$ primer, and five units of Taq polymerase (Cetus). The following conditions were used for the $P C R$ reaction: after five minutes denaturation at $94^{\circ} \mathrm{C}, 30$ cycles of 60 seconds denaturation at $94^{\circ} \mathrm{C}, 60$ seconds annealing at $60^{\circ} \mathrm{C}$, five to seven minutes extension at $72^{\circ} \mathrm{C}$ 


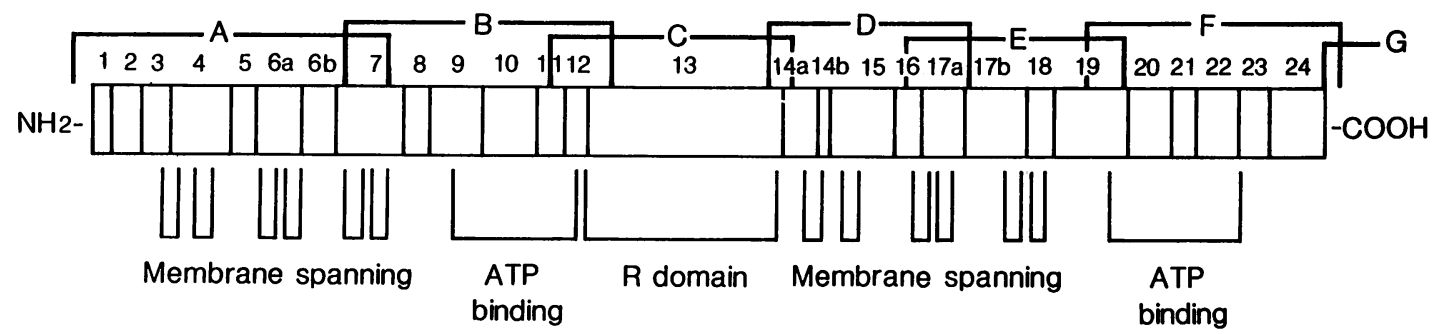

Figure 1 Diagram of the CF gene $c D N A$ to show overlapping segments amplified by each set of clustered PCR primers $(A-F)$ and their relation to the predicted functional domains of the protein.

Primer sequences used for PCR amplification of CF gene cDNA segments.

\begin{tabular}{|c|c|c|c|c|}
\hline Primer & & Sequence & & Fragment size \\
\hline $\begin{array}{l}A 1 R \\
A 2 R\end{array}$ & $\begin{array}{l}124 \\
156\end{array}$ & $\begin{array}{l}\text { CGAGAGACCATGCAGAGGTC } \\
\text { GGCCAGCGTTGTCTCCAAAC }\end{array}$ & & \multirow{2}{*}{1033} \\
\hline $\begin{array}{l}A 2 L \\
A 1 L\end{array}$ & & $\begin{array}{l}\text { gccgagtgaccgccatgcgc } \\
\text { gctccaagagagtcatacca }\end{array}$ & $\begin{array}{l}1189 \\
1232\end{array}$ & \\
\hline $\begin{array}{l}B 1 R \\
B 2 R\end{array}$ & $\begin{array}{r}998 \\
1022\end{array}$ & $\begin{array}{l}\text { GACAAACAGAACTGAAACTG } \\
\text { GGAAGGCAGCCTATGTGAGA }\end{array}$ & & \multirow[b]{2}{*}{898} \\
\hline $\begin{array}{l}B 2 L \\
B 1 L\end{array}$ & & $\begin{array}{l}\text { agccatcagtttacagacac } \\
\text { cagctttctttaaatgttcc }\end{array}$ & $\begin{array}{l}1920 \\
1972\end{array}$ & \\
\hline $\begin{array}{l}C 1 R \\
C 2 R\end{array}$ & $\begin{array}{l}1777 \\
1812\end{array}$ & $\begin{array}{l}\text { GTGGAGGTCAACGAGCAAGA } \\
\text { AGCAGTATACAAAGATGCTG }\end{array}$ & & \multirow{2}{*}{769} \\
\hline $\begin{array}{l}C 2 L \\
C 1 L\end{array}$ & & $\begin{array}{l}\text { tcttcacttatttccaagcc } \\
\text { actcctttaagtcttcttcg }\end{array}$ & $\begin{array}{l}2581 \\
2626\end{array}$ & \\
\hline $\begin{array}{l}D 1 R \\
D 2 R\end{array}$ & $\begin{array}{l}2490 \\
2530\end{array}$ & $\begin{array}{l}\text { GACAACAGCATCCACACGAA } \\
\text { GCAAACTTGACTGAACTGGA }\end{array}$ & & \multirow{2}{*}{729} \\
\hline $\begin{array}{l}D 2 L \\
D 1 L\end{array}$ & & $\begin{array}{l}\text { gttgtttgagttgctgtgag } \\
\text { aattggactcctgecttcag }\end{array}$ & $\begin{array}{l}3259 \\
3283\end{array}$ & \\
\hline $\begin{array}{l}E 1 R \\
E 2 R\end{array}$ & $\begin{array}{l}3055 \\
3082\end{array}$ & $\begin{array}{l}\text { AGATTCTCCAAAGATATAGC } \\
\text { GATGACCTTCTGCCTCTTAC }\end{array}$ & & \multirow{2}{*}{699} \\
\hline $\begin{array}{l}E 2 L \\
E 1 L\end{array}$ & & $\begin{array}{l}\text { ctgtgagatctttgacagtc } \\
\text { gaaatgttgtctaatatggc }\end{array}$ & $\begin{array}{l}3781 \\
3824\end{array}$ & \\
\hline $\begin{array}{l}F 1 R \\
F 2 R\end{array}$ & $\begin{array}{l}3722 \\
3754\end{array}$ & $\begin{array}{l}\text { ACGTGAAGAAAGATGACATC } \\
\text { GGCCAAATGACTGTCAAAGA }\end{array}$ & & \multirow[b]{2}{*}{877} \\
\hline $\begin{array}{l}F 2 L \\
F 1 L\end{array}$ & & $\begin{array}{l}\text { catgtcaacatttatgctgc } \\
\text { cgagctccaattccatgagc }\end{array}$ & $\begin{array}{l}4599 \\
4627\end{array}$ & \\
\hline$G 1 R$ & 4524 & GCTGCTCTGAAAGAGGAGAC & & \multirow{2}{*}{760} \\
\hline$G 1 L$ & & agattataacagccctttcc & 5310 & \\
\hline $\begin{array}{l}H 1 R \\
H 1 L\end{array}$ & 5127 & $\begin{array}{l}\text { GAATACCACAGGAACCACAA } \\
\text { gcagtcttcttaagagtcag }\end{array}$ & 6072 & 945 \\
\hline
\end{tabular}

depending on the length of the cDNA segment; a final polymerisation step was carried out at $72^{\circ} \mathrm{C}$ for five minutes. A total of $1 \mu$ l of the first PCR reaction was then transferred to $49 \mu$ l of a PCR buffer premix as above but containing $500 \mathrm{ng}$ of each primer in the inside pair of the clustered set and $0.5 \mathrm{mmol} / 1$ dNTPs. A further 30 to 35 cycles of amplification were done using the same parameters as for the first reaction.

The products of each PCR reaction are shown in fig 2, where one-fifth of a second round PCR reaction on $1 \mu \mathrm{g}$ of total RNA from lymphoblastoid cell lines (1) and from peripheral blood lymphocytes (2) have been analysed on a $5 \%$ polyacrylamide 


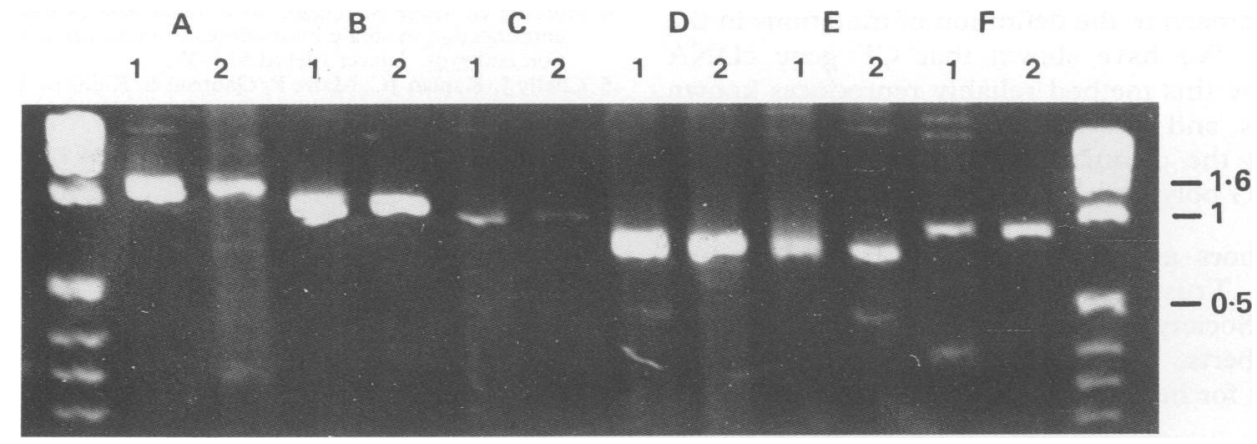

Figure 2 Fragments $A$ to $F$ of the $C F$ gene, PCR amplified after cDNA synthesis from $1 \mu g$ of total RNA from (1) a lymphoblastoid cell line and (2) lymphocytes; $10 \mu l$ of a $50 \mu l$ PCR reaction separated on a $5 \%$ polyacrylamide gel.

minigel. All sets of primers functioned efficiently, though the yield with set $C$ was always lower than with the other primer sets in the same RNA sample. Lowering of the annealing temperature of the PCR reaction to $58^{\circ} \mathrm{C}$ increased the yield. Each CF cDNA fragment was digested with at least one restriction enzyme to confirm the identity of the PCR product, based on the published CDNA sequence (data not shown).

In order to establish the fidelity of the 'ectopic' CF gene transcript in lymphocytes, we first attempted to detect the $\triangle F 508$ mutation in exon 10 in known carrier subjects. RNA from the $B$ region of the gene sequence which includes this mutation (fig 1) was reverse transcribed, amplified by PCR, and subjected to chemical mismatch analysis. ${ }^{10}$ Where the PCR reaction yielded small amounts of nonspecific product, the fragment of interest was purified on agarose gels before GeneClean (Bio 101) separation. Fig 3 shows a mismatch reaction with different ratios of control to patient ( $\triangle F 508$ carrier) DNA in the hybrid annealing step. Though with ratios of 1:10 and 1:20 control:patient DNA we were unable to detect the three base pair deletion at base 1654 , when the ratio was increased to $1: 30$ or $1: 40$, mismatch bands of about 635 and 265, corresponding to the two cleavage products caused by the $\triangle$ F508 deletion, were clearly visible after both osmium and hydroxylamine modification. The three $T$ residues in the mismatch are detected by the osmium tetroxide modification and a $\mathrm{C}$ residue adjacent to the deletion, and so destabilised, is modified by hydroxylamine.

A polymorphism has been shown to occur at base 1540 of the CF cDNA sequence ${ }^{11}$ where an $A$ or $G$ may occur. A $380 \mathrm{bp}$ mismatch band seen on fig 3 corresponds to a mutation $380 \mathrm{bp}$ from the $3^{\prime}$ end of fragment $B$ at $1920 \mathrm{bp}$. Sequence analysis of cDNA and genomic DNA from this subject showed the $A 1540 \rightarrow G$ base change (data not shown).
The establishment of a reliable method for detecting the CF gene transcript in peripheral blood lymphocytes and lymphoblastoid cell lines opens up

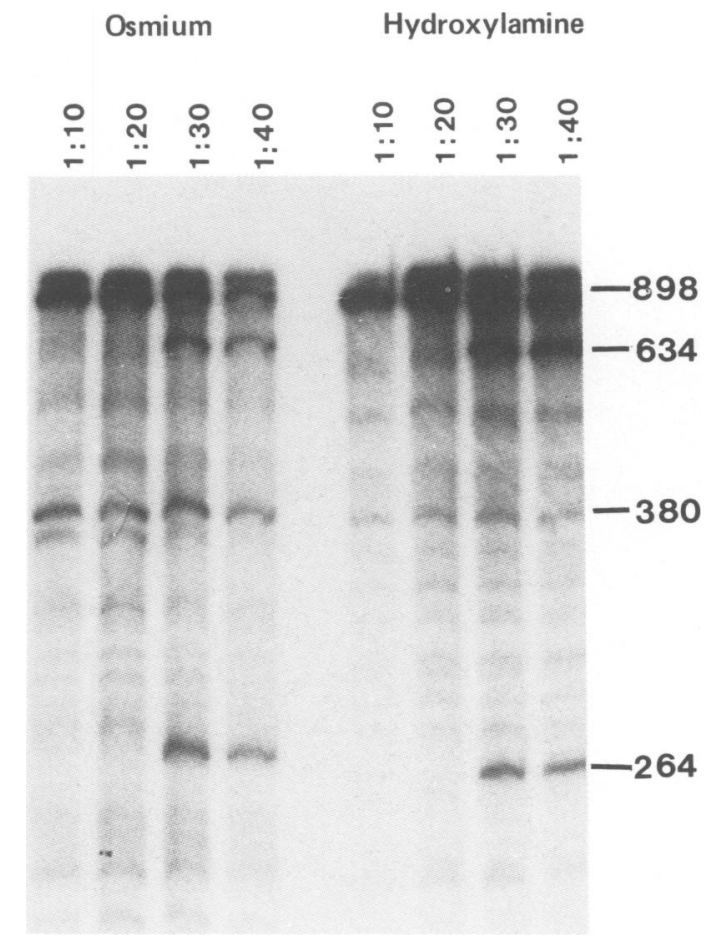

Figure 3 Autoradiograph of a $6 \%$ denaturing polyacrylamide gel showing a chemical mismatch reaction between control normal DNA segment $B$ and the same segment from a $C F$ patient, heterozygous for the $\triangle F 508$ mutation, after purification of both with Geneclean (Bio 101). Different ratios of probe:patient DNA have been used 1:10 to 1:40. The first four lanes show mismatches after osmium modification and the right four lanes after hydroxylamine modification. Fragment $B$ is $898 \mathrm{bp}$. 
a new approach to the definition of mutations in the $\mathrm{CF}$ gene. We have shown that $\mathrm{CF}$ gene cDNA isolated by this method reliably reproduces known mutations and polymorphisms in the CF gene including the common $\triangle$ F508 mutation and the A1540 $\rightarrow$ G polymorphism.

The authors are grateful to the Cystic Fibrosis Research Trust, the Generation Trust, and the Spastics Society for supporting this work. We thank Roli Roberts, Jane Montandon, and Francesco Giannelli for helpful discussions.

1 Riordan JR, Rommens JM, Kerem BS, et al. Identification of the cystic fibrosis gene: cloning and characterisation of complementary DNA. Science 1989;245:1066-73.

2 Kerem BS, Rommens JM, Buchanan JA, et al. Identification of the cystic fibrosis gene: genetic analysis. Science 1989; 245:1073-80.

3 Harris A, Chalkley GC, Goodman SA, Coleman LS. Expression of the cystic fibrosis gene in early human development. Development 1991;113:305-11.
4 Holding C, Monk M. Diagnosis of beta-thalassaemia by DNA amplification in single blastomeres from mouse preimplantation embryos. Lancet 1989;il:523-35.

5 Chelly J, Kaplan JC, Maire P, Gautron S, Kahn A. Transcription of the dystrophin gene in human muscle and non-muscle tissues. Nature 1988;333:858-60.

6 Roberts R, Bentley DR, Barby TFM, Manners E, Bobrow M. Direct diagnosis of carriers of Duchenne and Becker muscular dystrophy by amplification of lymphocyte RNA. Lancet 1990;336:1523-6.

7 Berg LP, Wieland K, Millar DS, et al. Detection of a novel point mutation causing haemophilia $A$ by PCR/direct sequencing of ectopically-transcribed factor VIII mRNA. Hum Genet 1990;85:655-8.

8 Chromczynski P, Sacchi N. Single-step method of RNA isolation by acid guanidinium thiocyanate-phenol-chloroform extraction. Anal Biochem 1987;162:156-9.

9 Chirgwin JM, Przybyla AE, Macdonald RJ, Rutter WJ. Isolation of biologically active ribonucleic acid from sources enriched in ribonuclease. Biochemistry 1979;18:5294-9.

10 Montandon AJ, Green PM, Giannelli F, Bentley DR. Direct detection of point mutations by mismatch analysis: application to haemophilia B. Nucleic Acids Res 1989;17:3347-58.

11 Kerem BS, Zielenski J, Markiewicz D, et al. Identification of mutations in regions corresponding to the two putative nucleotide (ATP)-binding folds of the cystic fibrosis gene. Proc Natl Acad Sci USA 1990;87:8446-51. 